\title{
Effect of clay content on strength and permeability of plastic loess-cement
}

\author{
Boriana Tchakalova \\ Geological Institute, Bulgarian Academy of Sciences, Acad. G. Bonchev Str., Bl. 24, 1113 Sofia, Bulgaria; \\ e-mail: boriana@geology.bas.bg
}

(Accepted in revised form: July 2019)

\begin{abstract}
Plastic soil-cement is a type of soil stabilization used for the treatment of natural soil to improve its engineering properties. It is a hardened material prepared by mixing soil and Portland cement at a water content higher than optimum, usually near the liquid limit, without compaction at optimum water content to maximum dry density. In Bulgaria, this soil stabilization technique has been applied in foundation works in collapsible loess ground in order to replace a part of the collapsible layer, to increase the bearing capacity of the soil base and/or to isolate the geoenvironment from migration of pollutants.

The aim of the current paper is to examine the effect of the clay content of the loess soil on the strength and permeability of plastic loess-cement. Results from the investigation indicate that the mechanical and hydraulic properties of the plastic loess-cement highly depend on the presence of clay fraction.
\end{abstract}

Tchakalova, B. 2019. Effect of clay content on strength and permeability of plastic loess-cement. Geologica Balcanica 48 (2), 25-30.

Keywords: soil stabilization, loess-cement, geotechnical parameters, clay fraction.

\section{INTRODUCTION}

Plastic admixture soil stabilization is used to improve the consistency, strength, deformation characteristics and permeability of problematic soils such as soft soils, collapsible loess soils, etc. The improvement becomes possible by the ion exchange at the surface of clay minerals, bonding of soil particles and/or filling of void spaces by chemical reaction products. Although a variety of chemical binders have been developed and used, the most frequently used binders nowadays are lime and cement, due to their availability and cost (Kitazume and Terashi, 2013).

Plastic soil stabilization represents mixing of soil with hydraulic binders, at water content normally much above the liquid limit $\left(w_{L}\right)$, without compaction at optimum water content to maximum dry density. Due to pozzolanic reactions between the binder and the soil grains, a hardened material with higher strength, lower permeability and better retardation characteristics is formed. Plastic soil-cement exhibits a number of advantages (Bell, 1993).
It acquires higher strength after longer curing period than the strength of compacted soil-cement. It has been established that the strength of a impervious bottom screen of irrigation water basin built by plastic loess-cement has increased from $0.7-$ $0.8 \mathrm{MPa}$ on the $28^{\text {th }}$ day to $10-12 \mathrm{MPa}$ after 51 years of curing, i.e., operation of the screen (Tchakalova, 2018). Normally, preparation of plastic soil-cement is performed by stationary mixing installations (a double-shaft mixer or other mechanical mixer) and, as a result, good homogenization is achieved and the built barriers are uniform. Plastic soil-cement has been applied most often to line or pave ditches for protection of slopes and other areas that are subject to erosion.

This soil stabilization technique has been applied in Bulgaria in collapsible loess terrains in order to increase the bearing capacity of the ground base and/or to play a role of engineering barrier against migration of pollutants in the geoenvironment (Evstatiev and Karastanev, 2013). Many factors affect the physical and mechanical parameters of loess-cement. Grain-size composition is one of 
the most important properties that affect the loess improvement. Evstatiev (1965, 1973, 1984, 1987) reported many experimental results on the influence of grain-size composition of loess on the response of cement stabilization. These data concern loesscement compacted at optimum water content to maximum dry density.

Typically, the grain-size composition of loess is characterized by a high content (80-90\%) of silt particles $(0.002-0.063 \mathrm{~mm})$, while the sand fraction $(0.063-2 \mathrm{~mm})$ is up to $10 \%$ and the clay fraction $(<0.002 \mathrm{~mm})$ varies from $0 \%$ to $15 \%$. In fact, the main variable in the grain-size composition of loess is the clay content. In the loess province of Bulgaria, the clay content of loess soils increases in depth and gradually in southern direction from the Danube River (Fig. 1) (Minkov, 1968).

The aim of the current paper is to examine the effects of clay content in loess soils on the strength and permeability of plastic loess-cement.

\section{MATERIALS AND METHODS}

\section{Materials}

\section{Loess soil}

Two samples of loess soil were used in the study. They were obtained near the town of Kozloduy, which is situated in the loess region of North Bulgaria (Fig. 1). The soil samples were collected by auger drilling technique at two depths: $2.0-2.50 \mathrm{~m}$ (sample L-1) and 9.50-10.0 m (sample L-2).

In order to characterize these soils, a series of classification and index tests, following the respective BDS-EN, standards were performed. They include determination of grain-size distribution (BDS-EN ISO 17892-4), liquid and plastic limits (BDS-EN ISO 17892-12) and particle density (BDS-EN ISO 17892-3). The test results and the corresponding soil classifications, in accordance with ESCS and AASHTO, are presented in Table 1.

The grain-size distribution curves of both samples are shown in Figure 2. It can be seen that the samples contain $92 \%$ of fine particles $(<0.063 \mathrm{~mm})$. Meanwhile, sample L-2 contains $12 \%$ clay $(<0.002 \mathrm{~mm})$ and is characterized by a uniform grain-size distribution $\left(C_{u}>6.0\right)$, whereas sample L-1 does not contain clay fraction at all and shows poor grain-size distribution $\left(C_{u}<6.0\right)$ (Table 1). Practically, the only difference between the two loess samples is the content of the clay fraction: $0 \%$ in $\mathrm{L}-1$ and $12 \%$ in $\mathrm{L}-2$.

This variation in grain-size composition induces difference of the plasticity limits of the samples (Fig. 3, Table 1): $I_{p}=9.7 \%$ for L-1 and $I_{p}=18.3 \%$ for L-2. Therefore, the two samples are classified by different group names according to ESCS (CIL Low plasticity clay for L-1 and CIM Medium plasticity

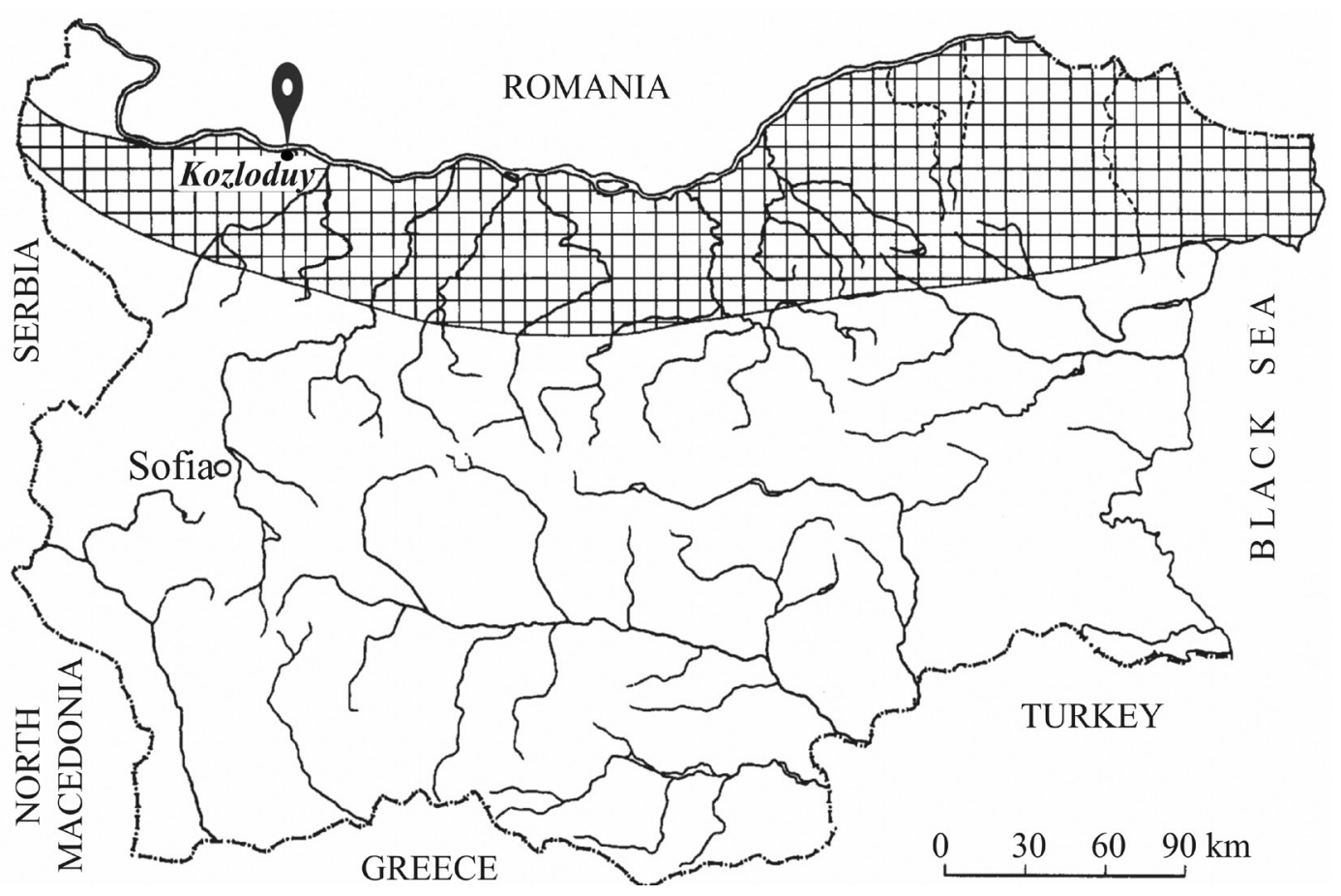

Fig 1. Loess province in Bulgaria (after Evstatiev et al., 2000) and location of the loess samples (Kozloduy). 
Table 1

Index parameters and classification of the tested loess samples

\begin{tabular}{lc|c|c}
\hline & Soil sample No. & L-1 & L-2 \\
& & & \\
\hline Parameter & $\mathrm{Mg} / \mathrm{m}^{3}$ & 2.73 & 2.76 \\
\hline $\begin{array}{l}\text { Particle density, } \rho_{s} \\
\text { Grain-size distribution: }\end{array}$ & $\%$ & 8 & 8 \\
Sand $(0.063-2 \mathrm{~mm})$ & $\%$ & 92 & 80 \\
Silt $(0.002-0.063 \mathrm{~mm})$ & $\%$ & - & 12 \\
Clay $(<0.002 \mathrm{~mm})$ & - & 2.7 & 22.7 \\
Uniformity coefficient, $C_{u}$ & - & 0.9 & 6.1 \\
Coefficient of curvature, $C_{c}$ & - & 30.2 & 36.2 \\
Liquid limit, $w_{L}$ & $\%$ & 20.4 & 17.3 \\
Plastic limit, $w_{P}$ & $\%$ & 9.7 & 18.3 \\
Plasticity index, $I_{P}$ & & CIL & CIM \\
ESCS classification & & A-4 & A-6 \\
AASHTO classification & & & \\
\hline
\end{tabular}

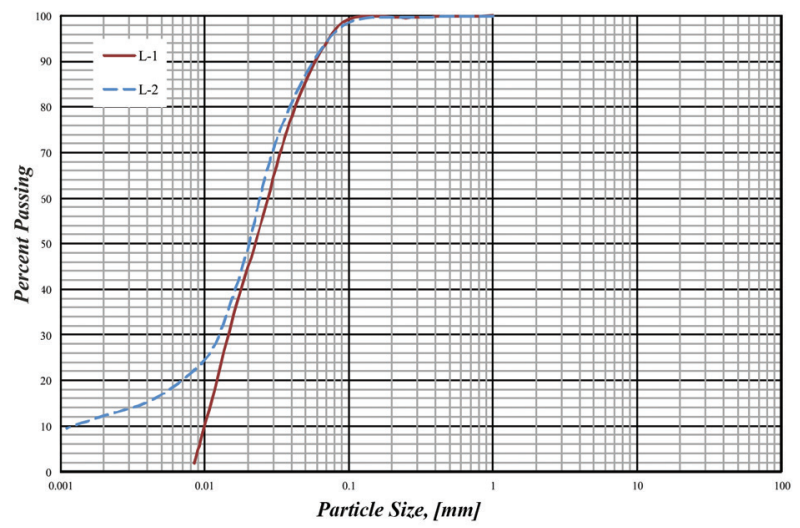

Fig. 2. Grain-size distribution curves of the used loess soils.

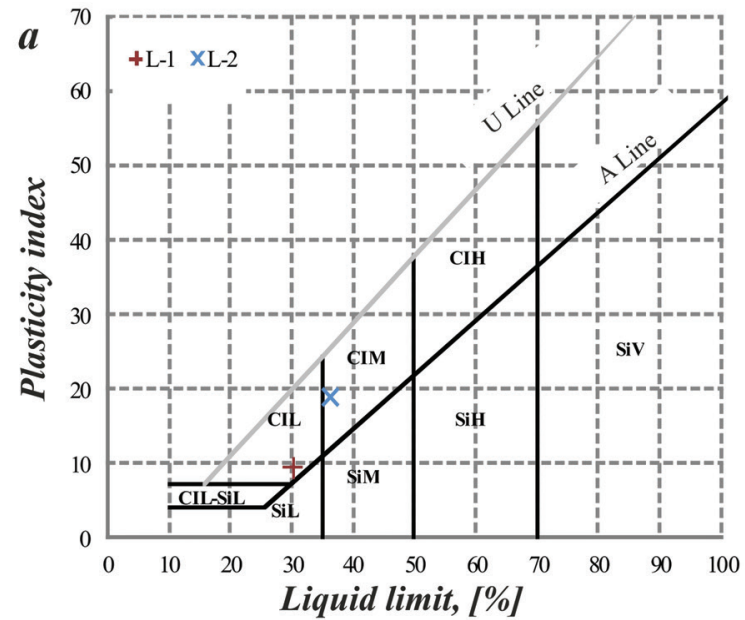

clay for L-2) and AASHTO (A-4 for L-1 and A-6 for L-2).

\section{Cement and water}

Portland cement CEM II $32.5 \mathrm{~N} 5$ according to the classification of cement in BDS-EN 197-1. Drinking water was used for preparation of the loess-cement test specimens, which is considered suitable for making concrete and soil-cement according to BDS-EN 1008:2003 and ASTM D 1632-07 and does not need examination.

\section{Test methods}

\section{Soil-cement specimen preparation}

All samples were prepared according to the JGS 0821 standard of the Japanese Geotechnical Society and moulded in a mould having a height of $100 \mathrm{~mm}$ and a diameter of $50 \mathrm{~mm}$. The stabilized specimens were prepared by mixing the soils with $10 \%$ of Portland cement with respect to the weight of dry soils at $40 \%$ water content with respect to the weight of dry ingredients. Mixture proportions are presented in Table 2.

Prior to the preparation of specimens, the soils were initially sifted through a No. 10 sieve, well homogenized and then oven-dried at $110^{\circ} \mathrm{C}$. The Portland cement was thoroughly mixed with the loess soil, then water was added and the mixture was stirred again. The cylindrical samples were prepared by pouring the mixture into a plastic mould in three layers (Fig. 4a). In order to remove air bubbles from the mixture, each layer was tapped 25 times against a table surface. The samples were then sealed and

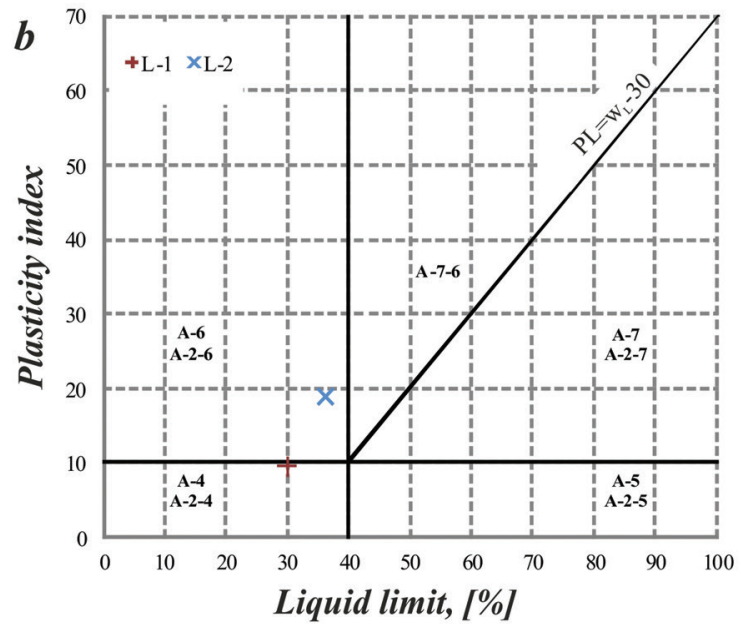

Fig. 3. Plasticity characteristics of the used loess soils based on ESCS ( $a$ ) and AASHTO (b). 

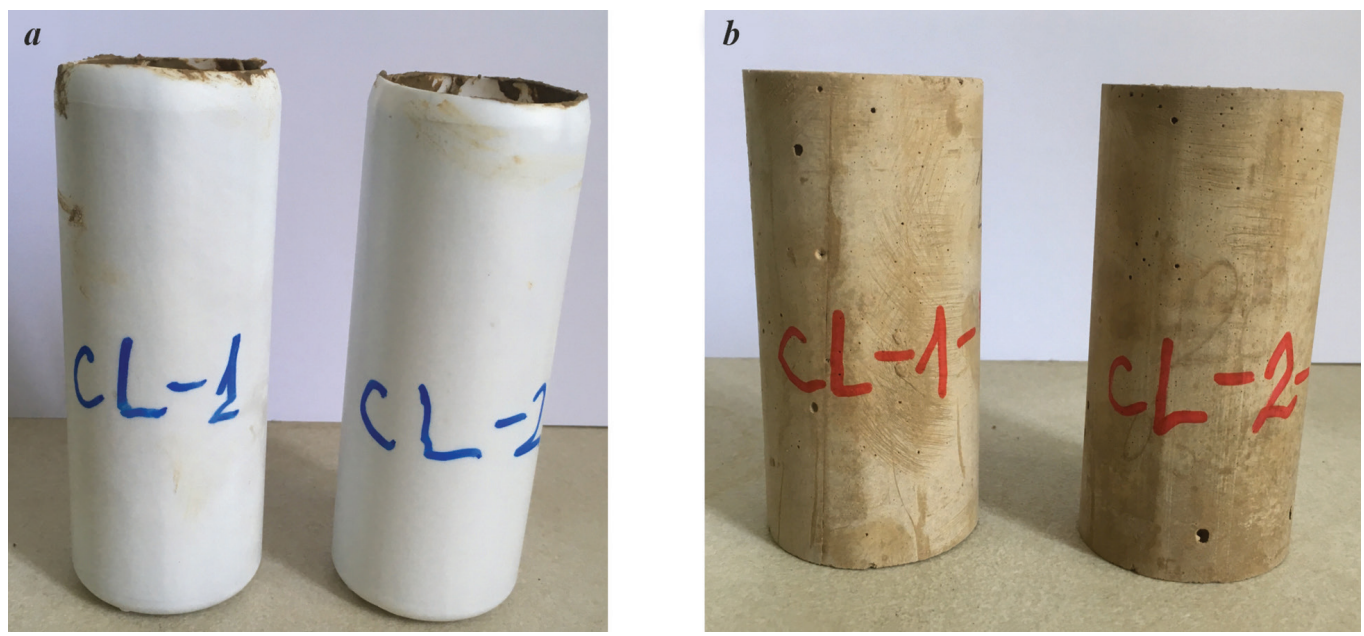

Fig. 4. Examples of test specimens: $a$ ) preparation; $b$ ) after 28 days of curing.

Table 2

Proportions of the tested loess-cement mixtures

\begin{tabular}{c|c|c|c}
\hline \multirow{2}{*}{ Mixture No. } & soil & cement & water \\
\cline { 2 - 4 } & $\mathrm{g}$ & $\mathrm{g}$ & $\mathrm{ml}$ \\
\hline cL-1 & 4000 & 400 & 1760 \\
cL-2 & 4000 & 400 & 1760 \\
\hline
\end{tabular}

stored in a curing room at a relative humidity of $95 \%$ and a temperature of $20^{\circ} \mathrm{C}$. After 28-day curing, the samples were taken out of the moulds, then cut and smoothed to have plain and parallel end surfaces, measured, weighed and tested.

\section{Unconfined compressive strength testing}

Compressive testing for the strength at the $28^{\text {th }}$ day was conducted in accordance with BDS-EN ISO 17892-8, using a compression testing device with displacement-controlled loading. Tests were carried out on cylindrical specimens with height to diameter (h/d) ratio of 2 (Fig. $4 b$ ). As specified in the ACI Report (1997), the ratio of 2 provides a more accurate measure of compressive strength from a technical standpoint, since it reduces complex stress conditions that may occur during crushing of lower $\mathrm{h} / \mathrm{d}$ samples.

UCS tests were performed under a constant strain rate of $1 \mathrm{~mm} / \mathrm{min}$. A group of four samples was tested for each mixture.

\section{Permeability testing}

The coefficient of permeability $k$ was determined by filtration tests, using the falling head method (Head,
1982). The temperature during the test was $20^{\circ} \mathrm{C}$ to maintain constant viscosity of water.

Before the assembly of the filtration cell (Fig. 5), the space between the specimen and the cell walls was covered once with water-impermeable cement-based mixture. Prior to the test, the filtration cell was subjected to vacuum until reaching full sample saturation.

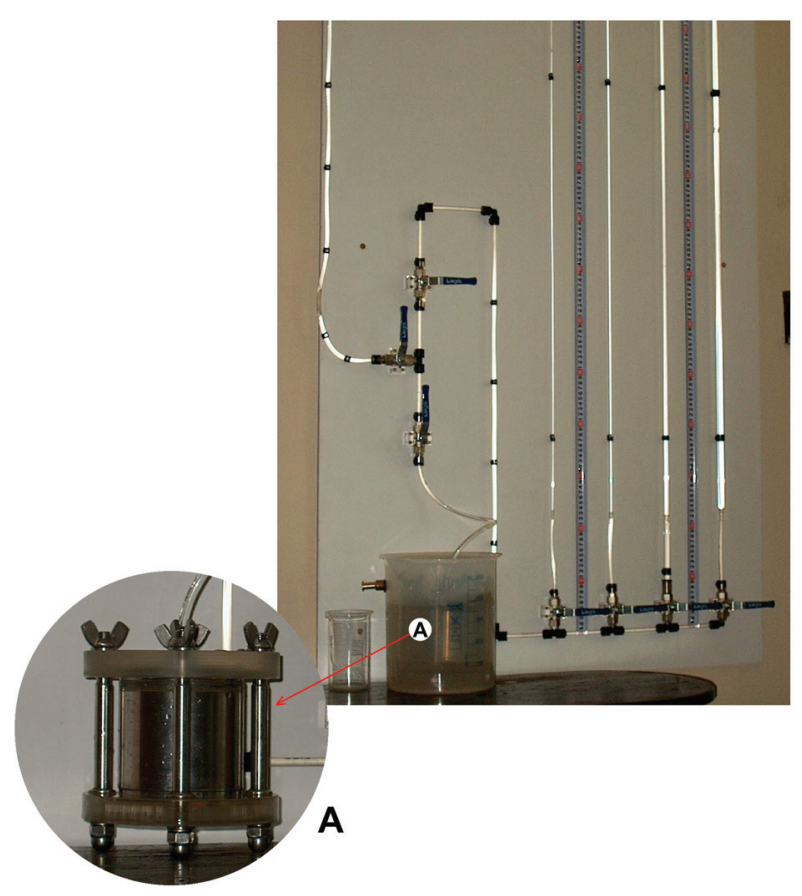

Fig. 5. Determination of the hydraulic conductivity with falling head method (A - filtration cell). 


\section{RESULTS AND DISCUSSION}

The stress-strain curves from the UCS tests of each specimen are presented in Fig. 6. For each mixture, the unconfined compressive strength $q_{u}$ was calculated by taking average $q_{u}$ value for the four tested specimens. The results are summarized in Table 3. On the basis of $q_{u}$ values, the undrained shear strength $s_{u}$ (Bowles, 1996) and secant modulus of elasticity $E_{50}$ (JIS A 1216) were also calculated and shown. The results for the coefficient of permeability $k$ for both mixtures are given in the same table.

Essential differences in strength and hydraulic conductivity values for both mixtures can be observed. Figure 2 clearly shows that, after 28 days

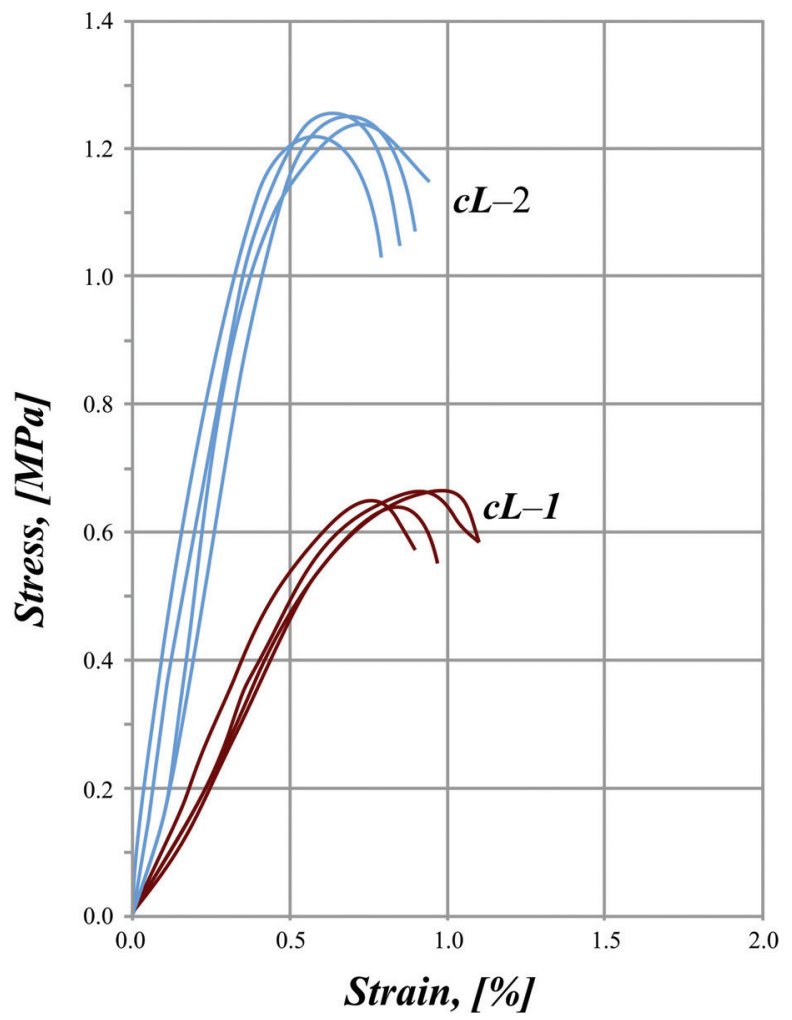

Fig. 6. Stress-strain relations of the tested mixtures.

Table 3

UCS and permeability obtained for the tested plastic loesscement mixtures

\begin{tabular}{c|c|c|c|c}
\hline \multirow{2}{*}{$\begin{array}{c}\text { Mixture } \\
\text { No }\end{array}$} & $q_{u 28}$ & $c_{u}$ & $E_{50}$ & $k$ \\
\cline { 2 - 5 } & {$[\mathrm{MPa}]$} & {$[\mathrm{MPa}]$} & {$[\mathrm{MPa}]$} & {$[\mathrm{m} / \mathrm{s}]$} \\
\hline cL-1 & 0.66 & 0.33 & 100.3 & $5.62 \mathrm{E}-6$ \\
cL-2 & 1.24 & 0.62 & 50.7 & $9.45 \mathrm{E}-8$ \\
\hline
\end{tabular}

of curing, the mixture cL-2 (with clay fraction) possesses about $200 \%$ higher UCS and $\mathrm{E}_{50}$ than the mixture cL-1 (clayless mixture).

Similar results for the influence of the loess grain-size composition on the UCS of the compacted loess-cement have been reported by Evstatiev (1965, 1987). After 28 days of curing compacted loess-cement laboratory samples prepared with $10 \%$ cement have shown the following $q_{\mathrm{u}}$ values: 1.5-2.0 MPa for the samples with sandy loess, 2.5-3.5 MPa for the samples with typical loess and 5.0-6.0 MPa for the samples with clayey loess (Evstatiev and Karastanev, 2013). The permeability tests also show that hydraulic conductivity of the plastic loess-cement is strongly influenced by the presence of clay fraction. The $k$ value for the cL-2 mixture is about 60 times less than the one for the clayless mixture (cL-1).

The different mechanical and permeable behaviours of the analysed plastic loess-cement mixtures could be attributed to the different reaction mechanisms between cement and soils with different grain-size distribution. The presence of clay particles in the loess soil leads to more intensive chemical reactions and formation of more new aggregates and reduction in porosity in the plastic soil-cement matrix.

\section{CONCLUSIONS}

The results obtained from the described laboratorybased study allow the following conclusions to be drawn:

- the mechanical and hydraulic properties of the plastic loess-cement are highly dependable on the presence of clay fraction $(<0.002 \mathrm{~mm})$ in the stabilized loess soil;

- the plastic loess-cement with $12 \%$ of clay particles shows two times higher strength and deformation parameters after 28 days of curing than the plastic loess-cement with no clay fraction in the stabilized loess soil;

- the permeability of plastic loess-cement with $12 \%$ of clay particles is about two orders of magnitude less than the permeability of plastic loess-cement with no clay fraction in the stabilized loess soil.

\section{Acknowledgements}

The author wishes to thank two anonymous reviewers for their constructive reviews and suggestions, which improved the quality of the manuscript. 


\section{ABBREVIATIONS AND SYMBOLS}

$\begin{aligned} \text { AASHTO } & \text { American Association of State Highway and Transportation Officials } \\ \text { BDS-EN } & \text { Bulgarian State Standard European Norm } \\ \text { ESCS } & \text { European Soil Classification System } \\ \text { JGS } & \text { Japanese Geotechnical Society } \\ \text { JIS } & \text { Japanese Industrial Standard } \\ c_{u} & \text { Uniformity coefficient } \\ E_{50} & \text { Modulus of elasticity at 50\% of } q_{u},[\mathrm{MPa}] \\ G_{S} & \text { specific gravity, [-] } \\ I_{P} & \text { Plasticity index, [\%] } \\ k & \text { Coefficient of permeability, [m/s] } \\ q_{u} & \text { Unconfined compressive strength (UCS), kPa/MPa } \\ S_{u} & \text { Undrained shear strength, [MPa] } \\ w_{L} & \text { Liquid limit, [\%] } \\ w_{P} & \text { Plastic limit, [\%] }\end{aligned}$

\section{REFERENCES}

American Concrete Institute (ACI). 1997. State-of-the-Art Report on Soil Cement. ACI 230.1R-90. Reapproved 1997. ACI Committee 230, 23 pp.

Bell, B.G.1993. Engineering Treatment of Soils. E \& FN Spon, London, 302 pp.

Evstatiev, D. 1965. Investigations on the cement stabilization of loess in Northern Bulgaria. Works on the geology of Bulgaria, series Engineering geology and hydrogeology 4, 131-153.

Evstatiev, D. 1973. Relationships between the strength parameters of loess cement mixtures. Bulletin of the Geological Institute of the Bulgarian Academy of Sciences, Series Engineering geology and hydrogeology 21-22, 87-101.

Evstatiev, D. 1984. Strength formation of soil-cement. Publishing House of the Bulgarian Academy of Sciences, Sofia, 94 pp. (in Bulgarian).

Evstatiev, D. 1987. Mechanism of the soil stabilization by means of hydraulic binders. DSc thesis, Geological Institute of the Bulgarian Academy of Sciences, Sofia, 301 pp. (unpublished).
Evstatiev, D., Karastanev, D. 2013. Investigation and applications of loess-cement in Bulgaria. Engineering Geology and Hydrogeology 27, 85-112 (in Bulgarian, with English abstract).

Head, U.H. 1982. Manual of Soil Laboratory Testing. Vol. 2. Pentech Press, London, 747 pp.

Jefferson I., Rogers, C., Evstatiev, D., Karastanev, D. 2005. Treatment of metastable loess soils: Lessons from Eastern Europe. Chapter 25. In: Buddhima, I, Chu, J. (Eds), Ground Improvement - Case Histories. Elsevier Geo-Engineering book series 3, 723-762.

Kitazume, M., Terashi, M. 2013. The deep mixing method. CRC Press Taylor \& Francis Group/Balkema, Boca Raton, London, New York, Leiden, 405 pp.

Minkov, M. 1968. The Loess in North Bulgaria. A Complex Study. Publishing House of the Bulgarian Academy of Sciences, Sofia, 202 pp. (in Bulgarian).

Tchakalova, B. 2018. Engineering barriers of plastic loesscement mixtures for waste isolation. PhD thesis, Geological Institute of the Bulgarian Academy of Sciences, Sofia, 135 pp. (unpublished). 